Fakultas Kedokteran Gigi Universitas Andalas

Jalan Perintis Kemerdekaan No. 77 Padang, Sumatera Barat

Web: adj.fkg.unand.ac.id Email: adj@dent.unand.ac.id

\title{
HUBUNGAN DIMENSI KUALITAS PELAYANAN PETUGAS ADMINISTRASI PENGELOLA BPJS KESEHATAN DENGAN KEPUASAN PASIEN RAWAT JALAN DI POLIKLINIK RSUD DR. RASIDIN PADANG
}

Nilam Devina ${ }^{1}$, Febrian $^{1}$, Murniwati $^{1}$

Korespondensi : nilamdevina8@ gmail.com Telp: 081277925301

\begin{abstract}
Administration service of BPJS Kesehatan is the start of whole service of medical service received by every patient. Service quality can be reflected by patients satisfaction after receiving service given by administration officer. Service quality on patients satisfaction is classified into five dimensions of competency, responsiveness, guarantee, emphaty and physical appearance. Dr. Rasyidin General Hospital is a hospital collaborating with BPJS Kesehatan that expected to give a good quality service on medical and non-medical aspects. Increasing public awareness and criticism demand a high quality service to gain the patients satisfaction
\end{abstract}

Keywords: Administration service, service quality dimensions, patients satisfactionc

Affiliasi penulis : 1. Departemen Ilmu Kesehatan Gigi Masyarakat, Fakultas Kedokteran Gigi Universitas Andalas,

\section{PENDAHULUAN}

Setiap orang mempunyai hak dalam memperoleh pelayanan kesehatan yang aman, bermutu, dan terjangkau. ${ }^{1}$ Jaminan Kesehatan merupakan jaminan berupa perlindungan kesehatan agar peserta memperoleh manfaat pemeliharaan kesehatan dan perlindungan dalam memenuhi kebutuhan dasar kesehatan yang diberikan kepada setiap orang yang telah membayar iuran atau iurannya dibayar oleh pemerintah. Badan Penyelenggara Jaminan Sosial (BPJS) Kesehatan merupakan badan hukum yang dibentuk untuk menyelenggarakan program Jaminan Kesehatan. ${ }^{2}$ Kesan pertama yang diperoleh masyarakat terhadap baik tidaknya kualitas pelayanan di bidang kesehatan, dimulai dari sistem pengurusan administrasi, karena pengurusan administrasi yang sederhana mudah dan cepat merupakan salah satu peningkatan pelayanan kepada pasien. ${ }^{3}$

Dalam rangka meningkatkan pelayanan kesehatan, rumah sakit sangat memerlukan sumber daya manusia yang mempunyai kinerja yang baik. Kinerja pegawai merupakan hasil dari suatu proses atau seperangkat proses yang menciptakan pemahaman bersama mengenai apa yang harus dicapai dan bagaimana hal itu dicapai serta bagaimana dapat mengatur orang dengan cara yang dapat meningkatkan kemungkinan tercapainya tujuan tersebut. ${ }^{4}$ Selain itu pemberi pelayanan atau petugas sebaiknya berpenampilan rapi dan berkomunikasi aktif untuk mendukung pelayanan. Tata cara melayani pasien dapat dinilai baik apabila dilaksanakan dengan cepat, sikap yang ramah, sopan, tertib dan penuh tanggung jawab oleh petugas. Agar menciptakan dan menjaga mutu pelayanan yang disesuaikan dengan keinginan dan harapan pasien, maka perlu suatu umpan balik dari pasien berupa tanggapan dan penilaian dari para pasien tersebut sehingga 
Fakultas Kedokteran Gigi Universitas Andalas Jalan Perintis Kemerdekaan No. 77 Padang, Sumatera Barat Web: adj.fkg.unand.ac.id Email: adj@dent.unand.ac.id

dijadikan sebagai suatu bahan evaluasi dan gambaran apakah pelayanan yang diberikan telah memenuhi harapan pasien atau belum. ${ }^{5}$

Rumah Sakit Umum Daerah (RSUD) dr. Rasidin Padang merupakan rumah sakit milik pemerintah tipe $\mathrm{C}$ yang terletak di kota Padang, provinsi Sumatera Barat, Indonesia. Rumah sakit ini merupakan salah satu rumah sakit rujukan bagi pasien Jaminan Kesehatan Nasional (JKN) yang bertanggung jawab dalam memberikan pelayanan kesehatan dengan mengutamakan penyembuhan dan pemulihan terhadap masyarakat kota Padang. RSUD dr. Rasidin memiliki produk layanani instalasi rawat inap, instalasi rawat jalan, dan instalasi gawat darurat. ${ }^{6}$ Pada pelaksanaannya, RSUD dr. Rasidin Padang tidak terlepas dari peranan serta dukungan dari petugas administrasi dalam melaksanakan tugas dan fungsinya. Cakupan pelayanan administrasi pada unit rawat jalan tingkat lanjutan meliputi: biaya administrasi pendaftaran untuk berobat, penerbitan surat eligibilitas peserta, termasuk pembuatan kartu pasien. ${ }^{7}$

Parasuraman, Zeithaml, dan Berry tahun 1988 menyebutkan kualitas jasa pelayanan dapat diukur melalui metode Servqual. Metode Servqual memiliki lima dimensi utama yaitu tangibles (bukti fisik), reliability (kehandalan), responsiveness (daya tanggap), assurance (jaminan), dan emphaty (empati).8 Seseorang akan merasa puas apabila hasil yang dirasakannya sama/melebihi harapannya dan sebaliknya akan timbul perasaan kecewa atau ketidakpuasan apabila hasil yang dirasakannya tidak sesuai dengan harapan. ${ }^{9}$ Pelayanan yang baik merupakan pelayanan yang dapat memenuhi harapan dan kebutuhan pasien, salah satunya adalah pada pelayanan administrasi. Oleh karena itu, suatu kewajiban bagi RSUD dr. Rasidin Padang dalam memberikan pelayanan yang berfokus pada kepuasan pasien salah satunya dimulai dari pelayanan administrasi yang berkualitas.

\section{METODE}

Penelitian ini menganalisis hubungan dimensi kualitas pelayanan petugas pengelola administrasi BPJS kesehatan dengan kepuasan pasien JKN kesehatan di poliklinik rawat Jalan RSUD dr. Rasidin Padang dengan menggunakan metode penelitian deskriptif dengan pendekatan cross-sectional.

Sampel dalam penelitian ini diambil menggunakan teknik non-probability sample dengan cara consecutive sampling. Besar sampel pada penelitian dihitung dengan menggunakan rumus Lemeshow, dimana jumlah responden sebanyak 106 responden. 
Fakultas Kedokteran Gigi Universitas Andalas Jalan Perintis Kemerdekaan No. 77 Padang, Sumatera Barat Web: adj.fkg.unand.ac.id Email: adj@dent.unand.ac.id

\section{HASIL DAN PEMBAHASAN}

Tabel 1. Distribusi Frekuensi Kualitas Pelayanan Petugas Administrasi Berdasarkan Dimensi

\begin{tabular}{|c|c|c|c|c|c|c|c|c|c|c|}
\hline \multirow[t]{2}{*}{ Kategori } & \multicolumn{2}{|c|}{$\begin{array}{l}\text { Kehandal } \\
\text { an } \\
\text { (Reliabilit } \\
y)\end{array}$} & \multicolumn{2}{|c|}{$\begin{array}{c}\text { Daya } \\
\text { Tanggap } \\
\text { (Responsivene } \\
\text { ss) }\end{array}$} & \multicolumn{2}{|c|}{$\begin{array}{c}\text { Jaminan } \\
\text { (Assurance) }\end{array}$} & \multicolumn{2}{|c|}{$\begin{array}{c}\text { Empati } \\
\text { (Emphaty) }\end{array}$} & \multicolumn{2}{|c|}{$\begin{array}{c}\text { Tampilan } \\
\text { Fisik } \\
(\text { Tangible })\end{array}$} \\
\hline & $\mathrm{n}$ & $\%$ & $\mathrm{n}$ & $\%$ & $\mathrm{n}$ & $\%$ & $\mathrm{n}$ & $\%$ & $\mathrm{n}$ & $\%$ \\
\hline Baik & 74 & 69,8 & 69 & 65,1 & 67 & 63,2 & 61 & 57,5 & 56 & 52,8 \\
\hline $\begin{array}{l}\text { Tidak } \\
\text { Baik }\end{array}$ & 32 & 30,2 & 37 & 34,9 & 39 & 36,8 & 45 & 42,5 & 50 & 47,2 \\
\hline Total & $\begin{array}{c}10 \\
6\end{array}$ & $\begin{array}{c}100 \\
0\end{array}$ & 106 & 100,0 & 106 & $\begin{array}{c}100 \\
0\end{array}$ & 106 & 100,0 & 106 & 100,0 \\
\hline
\end{tabular}

Hasil dari tabel diatas menunjukkan bahwa responden yang menyatakan baik terhadap kualitas pelayanan administrasi berdasarkan dimensi kehandalan (Reliability) di Poliklinik Rawat Jalan RSUD dr. Rasidin Padang adalah sebanyak 69,8\%, Dimensi daya tanggap (Responsiveness) sebanyak 65,1\%, dimensi jaminan (Assurance) sebanyak 63,2\%, dimensi empati (Emphaty) $57,5 \%$, dimensi tampilan fisik (Tangible) 52,8\%.

Tabel 2. HubungaDimensi Daya Tanggap (Responsiveness) Dengan Kepuasan Pasien

\begin{tabular}{|c|c|c|c|c|c|c|}
\hline \multirow{3}{*}{ Daya Tanggap } & \multicolumn{4}{|c|}{ Kepuasan Pasien } & \multirow{3}{*}{ Total } & \multirow{3}{*}{$\mathrm{P}$ value } \\
\hline & \multicolumn{2}{|c|}{ Puas } & \multicolumn{2}{|c|}{ Tidak Puas } & & \\
\hline & $\mathrm{n}$ & $\%$ & $\mathrm{n}$ & $\%$ & & \\
\hline Baik & 67 & 97,1 & 2 & 2,9 & 69 & \\
\hline Tidak baik & 14 & 37,8 & 23 & 62,2 & 37 & 0,000 \\
\hline Total & 81 & 76,4 & 25 & 23,6 & 106 & \\
\hline
\end{tabular}

Berdasarkan Tabel 2 sebagian besar responden menyatakan puas terhadap pelayanan petugas administrasi BPJS Kesehatan lebih banyak pada dimensi daya tanggap yang baik $(97,1 \%)$ dan sebanyak $(62,2 \%)$ respondenmenyatakan tidak puas terhadap dimensi daya tanggap. Berdasarkan uji statistik didapatkan ( $\mathrm{p}$ value $<0,05=0,000$ ) sehingga terdapat hubungan bermakna antara kualitas pelayanan petugas administrasi berdasarkan dimensi daya tanggap terhadap kepuasan pasien di poliklinik rawat jalan RSUD dr. Rasidin Padang. 
Fakultas Kedokteran Gigi Universitas Andalas Jalan Perintis Kemerdekaan No. 77 Padang, Sumatera Barat Web: adj.fkg.unand.ac.id Email: adj@dent.unand.ac.id

Tabel 3 Hubungan Dimensi Jaminan (Assurance) Dengan Kepuasan Pasien

\begin{tabular}{|c|c|c|c|c|c|c|}
\hline \multirow{3}{*}{ Jaminan } & \multicolumn{4}{|c|}{ Kepuasan Pasien } & \multirow{3}{*}{ Total } & \multirow{3}{*}{$P$ value } \\
\hline & \multicolumn{2}{|c|}{ Puas } & \multicolumn{2}{|c|}{ Tidak Puas } & & \\
\hline & $\mathrm{n}$ & $\%$ & $\mathrm{n}$ & $\%$ & & \\
\hline Baik & 63 & $\begin{array}{l}94, \\
0\end{array}$ & 4 & 6,0 & 67 & \\
\hline Tidak baik & 18 & $\begin{array}{l}46, \\
2\end{array}$ & 21 & 53,8 & 39 & 0,000 \\
\hline Total & 81 & $\begin{array}{l}76, \\
4\end{array}$ & 25 & 23,6 & 106 & \\
\hline
\end{tabular}

Berdasarkan Tabel 3 sebagian besar responden menyatakan puas terhadap pelayanan petugas administrasi BPJS Kesehatan lebih banyak pada dimensi jaminan yang baik $(94,0 \%)$ dan sebanyak $(53,8 \%)$ responden menyatakan tidak puas terhadap dimensi jaminan. Berdasarkan uji statistik didapatkan ( $\mathrm{p}$ value $<0,05=0,000$ ) sehingga terdapat hubungan bermakna antara kualitas pelayanan petugas administrasi berdasarkan dimensi jaminan terhadap kepuasan pasien di poliklinik rawat jalan RSUD dr. Rasidin Padang

Tabel 4 Hubungan Dimensi Empati (Empathy) Dengan Kepuasan Pasien

\begin{tabular}{|c|c|c|c|c|c|c|}
\hline \multirow{3}{*}{ Empati } & \multicolumn{4}{|c|}{ Kepuasan Pasien } & \multirow{3}{*}{ Total } & \multirow{3}{*}{$\mathrm{P}$ value } \\
\hline & \multicolumn{2}{|c|}{ Puas } & \multicolumn{2}{|c|}{ Tidak Puas } & & \\
\hline & $\mathrm{n}$ & $\%$ & $\mathrm{n}$ & $\%$ & & \\
\hline Baik & 57 & 93,4 & 4 & 6,6 & 61 & \\
\hline Tidak baik & 24 & 53,3 & 21 & 46,7 & 45 & 0,000 \\
\hline Total & 81 & 76,4 & 25 & 23,6 & 106 & \\
\hline
\end{tabular}

Berdasarkan Tabel 4 sebagian besar responden menyatakan puas terhadap pelayanan petugas administrasi BPJS Kesehatan lebih banyak pada dimensi empati yang baik $(93,4 \%)$ dan sebanyak $(46,7 \%)$ responden menyatakan tidak puas terhadap dimensi empati. Berdasarkan uji statistik didapatkan ( $\mathrm{p}$ value $<0,05=0,000$ ) sehingga terdapat hubungan bermakna antara kualitas pelayanan petugas administrasi berdasarkan dimensi empati terhadap kepuasan pasien di poliklinik rawat jalan RSUD dr. Rasidin Padang. 
Fakultas Kedokteran Gigi Universitas Andalas Jalan Perintis Kemerdekaan No. 77 Padang, Sumatera Barat Web: adj.fkg.unand.ac.id Email: adj@dent.unand.ac.id

Tabel 5 Hubungan Dimensi Tampilan Fisik (Tangible) Dengan Kepuasan Pasien

\begin{tabular}{|c|c|c|c|c|c|c|}
\hline \multirow{3}{*}{ Tampilan Fisik } & \multicolumn{4}{|c|}{ Kepuasan Pasien } & \multirow{3}{*}{ Total } & \multirow{3}{*}{$P$ value } \\
\hline & \multicolumn{2}{|c|}{ Puas } & \multicolumn{2}{|c|}{ Tidak Puas } & & \\
\hline & $\mathrm{n}$ & $\%$ & $\mathrm{n}$ & $\%$ & & \\
\hline Baik & 55 & 98,2 & 1 & 1,8 & 56 & \\
\hline Tidak baik & 26 & 52,0 & 24 & 48,0 & 50 & 0,000 \\
\hline Total & 81 & 76,4 & 25 & 23,6 & 106 & \\
\hline
\end{tabular}

Berdasarkan Tabel 5 sebagian besar responden menyatakan puas terhadap pelayanan petugas administrasi BPJS Kesehatan lebih banyak pada dimensi tampilan fisik yang baik $(98,2 \%)$ dan sebanyak $(48,0 \%)$ responden

menyatakan tidak puas terhadap dimensi tampilan fisik. Berdasarkan uji statistik didapatkan (p value $<0,05=0,000$ ) sehingga terdapat hubungan bermakna antara kualitas pelayanan petugas administrasi berdasarkan dimensi tampilan fisik terhadap kepuasan pasien di poliklinik rawat jalan RSUD dr. Rasidin Padang.

\section{Dimensi Mutu Pelayanan}

Hasil penelitian menunjukkan bahwa sebagian besar responden menilai kualitas pelayanan petugas administrasi berdasarkan dimensi kehandalan dinyatakan baik dengan persentase sebesar 69,8\%. Salah satu faktor pendukung baiknya kualitas pelayanan yang diberikan dapat dilihat dari kejelasan dan keakuratan informasi yang diberikan oleh petugas dan mudah dimengerti oleh pasien. Hasil ini sama seperti penelitian sebelumnya di RSUD Kefamenanu Kabupaten Timor Tengah Utara yang menyatakan bahwa sebanyak 90,0\% responden merasa pelayanan yang diberikan berdasarkan indikator kehandalan sudah baik hal ini dilihat dari prosedur pelayanan di Rumah Sakit yang dapat langsung dilayani dan tidak berbelit-belit. ${ }^{10}$

Berdasarkan dimensi daya tanggap hasil penelitian juga dinyatakan baik dengan persentase sebesar 65,1\%. Beberapa aspek pelayanan yang diberikan oleh petugas administrasi sudah dinilai baik oleh pasien, hal ini karena kesadaran atau keinginan yang dimiliki oleh petugas administrasi dalam merespon setiap keluhan pasien serta tidak membiarkan pasien menunggu terlalu lama untuk mendapatkan pelayanan. Hasil ini sejalan dengan penelitian sebelumnya di RSU Cakra Husada Klaten yang menyatakan bahwa kualitas pelayanan berdasarkan dimensi daya tanggap sudah kategorikan baik dapat dilihat dari keinginan petugas memberikan pelayanan dengan tanggap untuk membantu para pasien. ${ }^{11}$ 
Kualitas pelayanan petugas berdasarkan dimensi jaminan pada hasil penelitian dinyatakan baik dengan persentase sebesar 63,2\%. Salah satu faktor pendukung yang menyatakan bahwa pelayanan yang diberikan sudah baik dapat dilihat dari ketepatan waktu pelayanan yang diberikan, sikap sopan dan ramah yang dimiliki oleh petugas administrasi dalam memberikan pelayanan. Hal tersebut dapat menumbuhkan kepercayaan pasien terhadap pelayanan yang diberikan. Pada penelitian di RSUD Teluk Kuantan juga menunjukkan pelayanan sudah baik, karena petugas telah memberikan jaminan keamanan dalam pelayanan yang sesuai dengan harapan pasien. ${ }^{12}$

Berdasarkan Dimensi empati, hasil penelitian juga dinyatakan baik dengan persentase sebesar 57,5\%. Kesabaran dan kepedulian yang dimiliki oleh petugas administrasi terhadap keluhan yang dirasakan pasien pada saat pelayanan merupakan salah satu faktor yang menyebabkan baiknya dimensi empati . Pada penelitian sebelumnya di RSU Cakra Husada Klaten juga menyatakan bahwa persepsi kualitas pelayanan yang baik berdasarkan dimensi empathy meliputi kemudahan dalam melakukan komunikasi dengan pasien serta memahami kebutuhan pasien. $^{11}$

Hasil penelitian yang menilai kualitas pelayanan petugas berdasarkan dimensi tampilan fisik sudah baik dengan persentase sebesar 52,8\%. Kualitas dimensi tampilan fisik yang baik ini dilihat dari penampilan petugas yang rapih dan bersih dengan mengenakan seragam lengkap selama proses pelayanan, serta penampilan fisik yang didukung oleh ketersediaan ruang tunggu yang nyaman serta fisilitas yang menunjang terlaksananya pelayanan tersebut. Hal ini sejalan dengan penelitian yang dilakukan Nepe dkk (2017) yang menyatakan bahwa sebanyak 62,5\% responden di RSUD Kefamenanu Kabupaten Timor Tengah Utara merasa pelayanan yang diberikan berdasarkan indikator tampilan fisik sudah baik, seperti: rumah sakit terlihat indah, bersih, nyaman, rapi, rumah sakit memiliki ruang tunggu, peralatan medis, obat-obatan, WC serta sanitasi yang memadai. ${ }^{10}$

Secara keseluruhan, menunjukkan bahwa sebagian besar responden merasa puas terhadap pelayanan petugas administrasi BPJS Kesehatan di RSUD dr. Rasidin Padang yaitu sebesar 76,4\%. Hal ini sejalan dengan penelitian Wulandari dkk (2016) di RSUD Dr. H. Moch Ansari Saleh, menyatakan bahwa sebanyak $70 \%$ pasien merasa puas pada pelayanan administrasi yang diberikan karena hasil dari kepuasan tersebut menjadi tolak ukur meningkatnya citra rumah sakit. ${ }^{13}$ Lima dimensi mutu pelayanan dalam menentukan kualitas pelayanan tersebut, meliputi kehandalan (reliability), daya tanggap (responsiveness), jaminan (assurance), empati (emphaty), dan bukti fisik (tangible) merupakan indikator penentu kualitas pelayanan yang memiliki keterkaitan dengan indikator kepuasan terhadap pelayanan yang diberikan. 
Fakultas Kedokteran Gigi Universitas Andalas

Jalan Perintis Kemerdekaan No. 77 Padang, Sumatera Barat

Web: adj.fkg.unand.ac.id Email: adj@dent.unand.ac.id

\section{Hubungan Dimensi Mutu Dengan Kepuasan Pelayanan}

Berdasarkan penelitian mengenai hubungan dimensi kualitas pelayanan petugas administrasi BPJS Kesehatan berdasarkan dimensi kehandalan dengan kepuasan pasien BPJS Kesehatan di poliklinik rawat jalan RSUD dr. Rasidin Padang diperoleh hasil nilai $\mathrm{p}=0,000$ yaitu kecil dari 0,05. Hal ini berarti terdapat hubungan yang bermakna antara pelayanan petugas administrasi BPJS Kesehatan berdasarkan dimensi kehandalan (reliability) dengan kepuasan pasien BPJS Kesehatan di Poliklinik Rawat Jalan RSUD dr. Rasidin Padang. Dapat diartikan jika kemampuan dalam memberikan pelayanan yang cepat dan sangat baik serta sesuai dengan yang dijanjikan maka kepuasan pasien akan meningkat, hal ini menunjukkan bahwa kepuasan pasien sangat dipengaruhi oleh persepsi kualitas pelayanan. ${ }^{11}$

Terdapat hubungan yang bermakna terhadap dimensi daya tanggap pelayanan petugas administrasi dengan kepuasan pasien dengan hasil analisis menggunakan uji chi-square menunjukkan nilai $\mathrm{p}=0,000$ yaitu kecil dari 0,05 yang berarti keinginan petugas untuk membantu para pasien dan merespon pelayanan dengan cepat tanggap sangat berhubungan dengan kepuasan pasien. $^{11}$

Hubungan dimensi jaminan pelayanan administrasi dengan kepuasan pasien Kesehatan di poliklinik rawat jalan menggunakan uji chi-square menunjukkan nilai $\mathrm{p}=0,000$ yaitu kecil dari 0,05 yang berarti terdapat hubungan yang bermakna antara pelayanan administrasi yang meliputi ketepatan waktu jam pelayanan, sikap sopan dan ramah yang dimiliki oleh petugas akan menumbuhkan kepercayaan dan kepuasan pasien terhadap pelayanan yang diberikan. Kepuasan pasien dilihat dari dimensi assurance yang meliputi dapat kemampuan, pengetahuan, kesopanan, dan sifat dapat dipercaya yang dimiliki para staf atau petugas, dan bebas dari bahaya dan keraguraguan. $^{11}$

Hubungan dimensi empati petugas administrasi dengan kepuasan pasien diperoleh hasil analisis menggunakan uji chi-square menunjukkan nilai $\mathrm{p}=0,000$ yaitu kecil dari 0,05 . Hal ini berarti terdapat hubungan yang bermakna antara pelayanan petugas administrasi berdasarkan dimensi empati yang dapat dilihat dari kemudahan dalam melakukan komunikasi, memahami kebutuhan para pasien dengan kepuasan pasien. ${ }^{11}$

Berdasarkan penelitian mengenai hubungan dimensi kualitas pelayanan administrasi Kesehatan berdasarkan dimensi tampilan fisik (tangible) dengan kepuasan pasien di poliklinik rawat jalan RSUD dr. Rasidin Padang menggunakan uji chi-square menunjukkan nilai $\mathrm{p}=0,000$ yaitu kecil dari 0,05 . Hal ini berarti terdapat hubungan yang bermakna antara pelayanan petugas 
administrasi BPJS Kesehatan berdasarkan dimensi tampilan fisik yang meliputi kelengkapan fasilitas fisik, perlengkapan alat dan sarana yang memadai dengan kepuasan ${ }^{11}$.

\section{SIMPULAN}

Dari hasil penelitian dapat diambil kesimpulan bahwa

1. Respon responden terhadap pelayanan administrasi berdasarkan kelima dimensi kualitas pelayanan administrasi yaitu dimensi kehandalan (reliability), dimensi daya tanggap (responsiveness), dimensi jaminan (assurance), dimensi empati (emphaty), dimensi tampilan fisik (tangible) di poliklinik rawat jalan RSUD dr. Rasidin Padang sudah baik

2. Terdapat hubungan yang bermakna antara kelima dimensi kualitas pelayanan administrasi yaitu dimensi kehandalan (reliability), dimensi daya tanggap (responsiveness), dimensi jaminan (assurance), dimensi empati (emphaty), dimensi tampilan fisik (tangible) dengan kepuasan pasien di poliklinik rawat jalan RSUD dr. Rasidin Padang.

\section{KEPUSTAKAAN}

Undang-Undang Republik Indonesia Nomor 36 Tahun 2009 Tentang Kesehatan. Jakarta: Kementerian Kesehatan Republik Indonesia.

Kemenkes, RI. 2013. Peraturan Menteri Kesehatan No 71 Tahun 2013 Tentang Pelayanan Kesehatan Pada Jaminan Kesehatan Nasional. Jakarta: Kementerian Kesehatan RI.

Fadlun, F. 2017. Sistem Pelayanan Administrasi Rekam Medik Rawat Inap Di Rumah Sakit Umum Daerah (RSUD) Poso.Katalogis, 5(3), pp.12-21.

Suryadi, E. 2010. Analisis Peranan Leadership dan Budaya Organisasi terhadap Kinerja Pegawai. Manajerial, $8(16)$, pp.1-9.

Kuntoro, W. dan Istiono, W. 2017. Kepuasan Pasien Terhadap Kualitas Pelayanan diTempat Pendaftaran Pasien Rawat Jalan Puskesmas Kretek Bantul Yogyakarta. Jurnal Kesehatan Vokasional, 2(1), pp.140-147.

Badan Perencanaan Pembangunan Daerah (Bappeda) Kota Padang. 2017. http://bappeda.padang.go.id/up/download/09012015121142RENSTRA-RSUD-2014-2019.pdf_diakses pada 7 Desember 2017 pukul 17.43 WIB.

Panduan Praktis Pelayanan Kesehatan, 2014.https://bpjskesehatan.go.id/bpjs/dmdocuments/0455038740193d957326594ea0d87b5e.pdf diakses pada 12 November 2017 pukul 15.00 WIB.

Aghamolaei, T. dkk. 2014. Service Quality Assesment of a Referral Hospital in Southern Iran with SERVQUAL Technique: Patients Perspective. BMC Health Services Research 14:322.

Pohan, I. S. 2007. Jaminan Mutu Layanan Kesehatan. Jakarta : EGC. pp. 9

Nepe, L., Mudayati, S. dan Susmini, S., 2017. Hubungan Pelayanan Kesehatan Dengan Kepuasan Pasien Peserta BPJS di Rumah Sakit Umum Daerah Kefamenanu Kabupaten Timor Tengah Utara. Nursing News: Jurnal Ilmiah Mahasiswa Keperawatan, 2(2). 


\section{ANDALASDENTAL JOURNAL}

Fakultas Kedokteran Gigi Universitas Andalas Jalan Perintis Kemerdekaan No. 77 Padang, Sumatera Barat Web: adj.fkg.unand.ac.id Email: adj@dent.unand.ac.id

Utama, A. 2003. Analisis Pengaruh Persepsi Kualitas Pelayanan Terhadap Kepuasan Pelanggan Rumah Sakit Umum Cakra Husada Klaten. Jurnal Opsi, 1(2), 96-110.

Nengsih, R.S., 2016. Kualitas Pelayanan Bagi Peserta Badan Penyelenggara Jaminan Sosial (Bpjs) di Rumah Sakit Umum Daerah TelukKuantan. Jurnal Online Mahasiswa (JOM) Bidang Ilmu Sosial dan Ilmu Politik, 3(2), pp.1-15.

Wulandari, A. Adenan, A. and Musafaah, M. 2016. Hubungan Antara Persepsi Pada Pelayanan Administrasi Rawat Inap Dengan Kepuasan Keluarga Pasien Peserta Jaminan Kesehatan Nasional. Jurnal Publikasi Kesehatan Masyarakat Indonesia, 3(2). 